\title{
Field Performance of Transgenic Tomato with Reduced Pectin Methylesterase Activity
}

\author{
Denise M. Tieman, Kurt D. Kausch, Delila M. Serra, and Avtar K. Handa ${ }^{1}$ \\ Department of Horticulture, Purdue University, 1165 Horticulture Building, West Lafayette, \\ IN 47907-1165
}

Additional index words. Lycopersicon esculentum, antisense RNA, fruit solids, fruit $\mathrm{pH}$, shelf life, gene expression

\begin{abstract}
Transgenic 'Rutgers' 37-81^ tomato (Lycopersicon esculentum Mill.) homozygous for a pectin methylesterase (PME) antisense gene, which lowers PME activity and increases levels of soluble solids, was compared to azygous (a segregating line of $37-81^{\wedge}$ with 0 copies of the introduced gene) and wild-type 'Rutgers' in the field during Summer 1992 and 1993 to determine the effects of the introduced PME antisense gene on tomato plant growth, fruit set, fruit yield, and fruit processing attributes. Fresh and dry weight accumulation in transgenic plants was similar to wild-type 'Rutgers' and azygous 37-81^ lines during 1992 and 1993, indicating that the introduced PME antisense gene did not affect biomass accumulation. Transgenic plants showed an increase in fruit number and yield in $\mathbf{1 9 9 2}$ compared to wild-type 'Rutgers' and azygous $37-81^{\wedge}$, but no differences were observed among the three genotypes in 1993. Average fruit weight did not show significant differences among the three genotypes in 1992, but was lower in azygous and transgenic plants than wildtype plants in 1993. Transgenic fruit had higher soluble and total solids and higher pH than control fruit, but shelf life was somewhat shorter in transgenic fruit. Overall, these data indicate that introduction of the PME antisense gene, which improves the processing quality of tomatoes, does not adversely affect fruit yield or vegetative growth of plants.
\end{abstract}

Modification of plant gene expression by antisense, co-suppression, or over-expression of metabolizing enzymes has provided powerful tools for improving crop plants (Finnegan and McElroy, 1994; Tabler, 1993). Several genes with great potential to modify fruit shelf life have been identified, including 1aminocyclopropane-1-carboxylate (ACC) synthase, ACC deaminase, ACC oxidase, and polygalacturonase. Alteration in the expression of these genes during ripening has led to significant improvement in shelf life of tomatoes (Gray et al., 1992; Hamilton et al., 1990; Klee et al., 1991; Kramer et al., 1992; Oeller et al., 1991; Schuch et al., 1991). In addition to shelf life, processing characteristics, such as total and soluble solids, juice viscosity, lycopene levels and chemistry of pectins, are economically significant parameters of processing tomato cultivars. Breeding approaches have been used to improve processing potential of tomatoes, and success has been achieved in increasing soluble solids such as sugars and organic acids (Hewitt and Garvey, 1987; Rick, 1974; Stevens, 1986). However, little progress has been made in modifying quality of pectins present in tomato fruit. The chemistry of fruit pectins is an important factor in determining the processing quality of fruit juice, especially gelling characteristics. Higher molecular weight and increased degree of methyl-esterification have been suggested to improve quality of processed products made from fruit juice (Leach et al., 1993; Miers et al., 1967). Reduction in polygalacturonase (PG) activity in tomato using its antisense gene has been reported to improve tomato shelf life and increase Bostwick values of processed tomato juice (Kramer et al., 1992; Schuch et al., 1991).

Received for publication 29 Dec. 1994. Accepted for publication 29 Apr. 1995. This research was supported by a Consortium for Plant Biotechnology Research grant. This is journal paper No. 14597 of the Purdue Univ. Agricultural Experimental Station. We thank Jules Janick, Mike Hasegawa, and Joel Gaffe for critical reading of the manuscript; Darrell Daniels, Steve Siegelin, and Fred Pieper for managing the field trial plots; Mario Morales and James Simon for assistance with statistical analyses; and Joel Gaffe, Krishna Mishra, Beli Thakur, Ann Drayton, Martin Tiznado, and Allen Turner for assisting with the tomato harvests. The cost of publishing this paper was defrayed in part by the payment of page charges. Under postal regulations, this paper therefore must be hereby marked advertisement solely to indicate this fact.

'To whom reprint requests should be addressed.
We have introduced an antisense gene for pectin methylesterase (PME) into tomato under the control of the constitutive cauliflower mosaic virus 35S (CaMV 35S) promoter to develop transgenic tomatoes with reduced PME activity (Tieman et al., 1992). PME, which demethoxylates pectins, is believed to be involved in degradation of pectic cell wall components by lowering the degree of methoxylation of fruit pectins, thus making pectin more susceptible to depolymerization by PG (Pressey and Avants, 1982). In an earlier report, we demonstrated that tomatoes with reduced PME activity have altered pectin chemistry, including higher degree of pectin esterification and increased pectin molecularweight (Tieman et al., 1992). Greenhouse-grown transgenic fruit expressing a PME antisense gene also show higher levels of soluble solids (Tieman et al., 1992).

Since higher soluble solids and improved pectin chemistry are important parameters in determining processing quality, we evaluated transgenic tomato plants expressing a PME antisense gene to determine whether improved processing qualities are maintained stably under field conditions without any detrimental effects on plant growth. PME is an ubiquitous enzyme found in most tissues of all plants and has been implicated in various growth and developmental processes (Huber, 1983; Northcote, 1986; RexovaBenkova and Markovic, 1976; Sexton and Roberts, 1982). Since genes under the control of the CaMV 35S promoter are expressed in most plant tissues (Harpster et al., 1988; Odell et al., 1985), we also determined the effects of the introduced gene on other agronomically important traits, including plant fresh and dry weight accumulation, fruit set, and fruit ripening. We report here that lowered PME activity does not have any deleterious effect on plant growth and development, but slightly improves the total and soluble solid contents of ripe tomatoes.

\section{Materials and Methods}

Plant material. Wild-type 'Rutgers', transgenic $37-81^{\wedge}$, and azygous $37-81^{\wedge}$ lines were tested in field trials to determine the effects of lowered PME activity on various agronomic traits. Transgenic $37-81^{\wedge}$ and azygous $37-81^{\wedge}$ are segregating lines of the transformant $37-81^{\wedge}$ containing two (homozygous) and0 (azygous) 
copies, respectively, of the introduced PME antisense gene (Tieman et al., 1992). The original $37-81^{\wedge}$ transgenic $\left(\mathrm{T}_{1}\right)$ parental line was obtained by introducing a PME antisense gene into wild-type 'Rutgers' using Agrobacterium tumefaciens -mediated transformation (Tieman et al., 1992). Transgenic $37-81^{\wedge}$ and azygous 37$81^{\wedge}$ lines are maintained by selfing after each generation. During the 1992 trials, T4 lines were used, while T5 seeds obtained from the 1992 trials were used for the 1993 studies. Purity of each population was established using a polymerase chain-reaction assay for the introduced gene.

Field trial design. Tomato plants were grown in the field at the O'Neall Memorial Research Farm (Tippecanoe County, Ind.) in a randomized complete block design with four replications for each cultivar. Each row contained 10 plants spaced $46 \mathrm{~cm}$ apart, and rows were spaced $91 \mathrm{~cm}$ apart. The plot consisted of an experimental row and two guard rows for each block, with the same line grown in the experimental and guard rows of each block. All fruit at the red-ripe stage were harvested weekly, and total fruit weight and fruit number from each row were determined. Average fruit weight was determined by dividing total fruit weight by total fruit number collected from each row. Random fruit samples were selected from each row at each harvest and used to determine $\mathrm{pH}$,

A

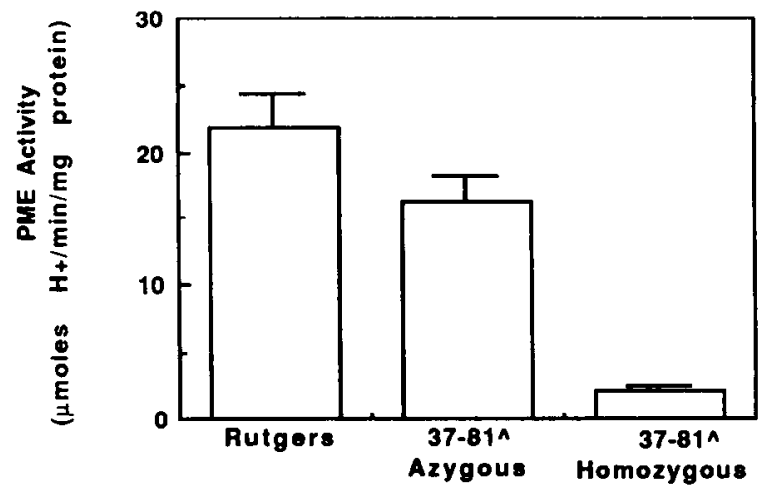

B

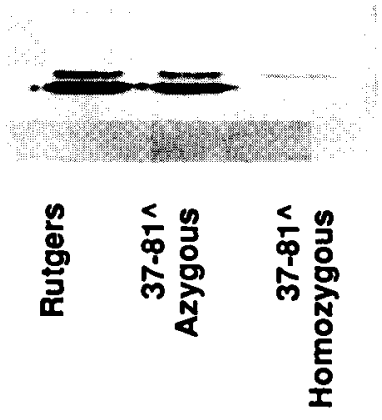

Fig. 1. Effects of the introduced PME antisense gene on PME gene expression. PME activity (A) and PME protein levels (B) in red ripe fruit from control 'Rutgers' and azygous $37-81^{\wedge}$ plants and transgenic $37-81^{\wedge}$ plants. For PME activity, bars represent means \pm SE of 10 independent samples for each genotype. For PME protein, $10 \mu \mathrm{g}$ total salt-extractable protein from ripe tomatoes was electrophoresed on $12 \%$ SDS-PAGE, blotted onto nitrocellulose and visualized using polyclonal fruit PME antibodies. The lower band represents the $34 \mathrm{kD}$ PME polypeptide (Tieman et al., 1992). soluble solids, and total solids content. Individual whole fruit were ground in a blender and $\mathrm{pH}$ was determined. An aliquot of the homogenate was centrifuged in an Eppendorf microcentrifuge and the supernatant was used to determine soluble solids ( $\left.{ }^{\circ} \mathrm{Brix}\right)$ with a refractometer. Total solids content was determined by freeze drying an aliquot of the homogenate and dry weight was calculated as a percentage of fresh weight. At the end of the growing season, all plants from the experimental rows were harvested individually from the ground level and weighed immediately to determine plant fresh weight. Dry weight was determined after drying plant tissue at 50C until a constant weight was obtained.

Fruit grade and shelf life. Freshly harvested fruit were graded for quality as described by Gould (1992) and according to the following: grade A was free of blemishes with even color development, grade B had minor or uneven color development, grade C had some blemishes without any signs of deterioration, while grade D had major blemishes and deterioration. Fruit shelf life was determined by storing ripe fruit at room temperature $(25 \pm 2 \mathrm{C})$. Fruit were considered unusable when the first signs of deterioration were observed.

PME activity and protein levels. PME activity and protein levels were determined by protein blotting with anti-PME antibodies as described earlier (Harriman et al., 1991; Tieman et al., 1992)

Statistical analysis. Data for the four experimental replicates were analyzed using SAS general linear model procedures (SAS Institute, Cary, N.C.).

\section{Results and Discussion}

Effects of the introduced antisense PME gene on PME gene expression. PME activity and protein levels in transgenic $37-81^{\wedge}$, azygous $37-81^{\wedge}$, and wild-type 'Rutgers' fruit were determined to show that the introduced antisense PME gene lowered PME gene expression in field-grown transgenic tomatoes in a manner similar to that seen in greenhouse-grown fruit (Tieman et al., 1992). As shown in Fig. 1, PME activity was reduced in transgenic fruit to $<10 \%$ of wild-type or azygous $37-81^{\wedge}$ control fruit. The levels of PME protein, as detected by immuno-blotting with PME antibodies, were also severely reduced in transgenic $37-81^{\wedge}$ fruit. The $34 \mathrm{kD}$ PME isozyme was not detectable in fruit of transgenic 37$81^{\wedge}$ plants. The levels of PME activity and protein in azygous $37-$ $81^{\wedge}$ fruit were similar to that of wild-type fruit, indicating that reduced $\mathrm{PME}$ gene expression in transgenic $37-81^{\wedge}$ fruit was due to the presence of the introduced PME antisense gene. Since seeds of the T5 generation were used for these studies, these results demonstrate that the effects of the introduced antisense PME genes are stably maintained during sexual propagation of transgenic plants.

Effects of the introduced gene on plant biomass and fruit yield. PME has been proposed to be involved in several growth and developmental processes in plants, including cell wall growth, maturation, and extensibility; cation binding capacity and modulation of $\mathrm{pH}$ of cell walls; ion acquisition and balance; cell wall porosity; and formation of abscission zones (Baron-Epel et al., 1988; Fry et al., 1993; Grignon and Sentenac, 1991; Moustacas et al., 1991; Nari et al., 1991; Rexova-Benkovaand Markovic, 1976; Sexton and Roberts, 1982). To determine the effects of the introduced gene on biomass accumulation, plants were harvested at the end of the growing season and total gains in fresh and dry weight were determined. As shown in Table 1, no significant differences were observed in fresh or dry weight of plants between wild-type 'Rutgers', azygous 37-81^ and transgenic 37-81^ during 1992 and 1993 trials. The ratio of dry weight to fresh weight was not different 
Table 1. Field evaluation of transgenic $37-81^{\wedge}$, azygous $37-81^{\wedge}$, and wild-type 'Rutgers' tomato plants during Summer 1992 and $1993 .{ }^{2}$

\begin{tabular}{|c|c|c|c|c|c|c|}
\hline Genotype & $\begin{array}{c}\text { Plant fresh } \\
\text { wt (g) }\end{array}$ & $\begin{array}{c}\text { Plant dry } \\
\text { wt (g) }\end{array}$ & $\begin{array}{l}\text { Plant dry } \\
\text { wt }(\%)\end{array}$ & $\begin{array}{l}\text { Fruit yield/ } \\
\text { plant (g) }\end{array}$ & $\begin{array}{l}\text { Avg fruit } \\
\text { weight (g) }\end{array}$ & $\begin{array}{c}\text { Fruit/ } \\
\text { plant (no.) }\end{array}$ \\
\hline \multicolumn{7}{|c|}{1992} \\
\hline Rutgers & $1930 \pm 199$ & $392 \pm 30$ & $20.9 \pm 0.6$ & $3075 \pm 220$ & $94.6 \pm 5.0$ & $32.6 \pm 2.0$ \\
\hline Azygous $37-81^{\wedge}$ & $2539 \pm 330$ & $474 \pm 31$ & $20.6 \pm 1.4$ & $3496 \pm 430$ & $88.3+2.9$ & $39.8 \pm 5.1$ \\
\hline Transgenic $37-81^{\wedge}$ & $2098 \pm 66$ & $401 \pm 20$ & $19.8 \pm 0.9$ & $3980 \pm 160$ & $89.4 \pm 2.5$ & $44.6 \pm 1.4$ \\
\hline \multicolumn{7}{|c|}{1993} \\
\hline Rutgers & $872 \pm 104$ & $183 \pm 18$ & $21.2 \pm 0.7$ & $2510 \pm 349$ & $100.3 \pm 3.0$ & $24.9 \pm 3.2$ \\
\hline Azygous $37-81^{\wedge}$ & $754 \pm 50$ & $150 \pm 13$ & $19.9 \pm 0.9$ & $2338 \pm 67$ & $80.1 \pm 3.5$ & $29.2 \pm 0.7$ \\
\hline Trangenic $37-81^{\wedge}$ & $817 \pm 16$ & $157 \pm 4$ & $19.3 \pm 0.6$ & $2157 \pm 250$ & $78.8 \pm 3.2$ & $27.2 \pm 2.1$ \\
\hline
\end{tabular}

"Numbers reported represent means \pm SE of four experimental rows of 10 plants each. Transgenic $3781^{\wedge}$ is homozygous for the introduced PME antisense gene, while azygous $37-81^{\wedge}$ is a segregating line with 0 copies of the introduced gene.

among the three genotypes for the two growing seasons. Additionally, we observed no phenotypic differences among the three genotypes. Lack of effect of the introduced gene on biomass accumulation and plant phenotype is likely due to the fact that we have used a PME gene, which is expressed only in fruit tissues (Harriman et al., 1991). The presence of multiple isoforms of PME in tomato and other crops has been demonstrated in various plant tissues (Gaffe et al., 1994; Sajjanantakul and Pitifer, 1991). We have shown earlier that accumulation of the PME isoform present in the vegetative tissues of tomato plants is not inhibited by the expression of a fruit specific PME antisense gene (Gaffe et al., 1994).

Total fruit yield per plant from transgenic $37-81^{\wedge}$ was not significantly different from wild-type or azygous $37-81^{\wedge}$ control plants in 1993, but higher fruit yield compared to 'Rutgers' was observed for transgenic $37-81^{\wedge}$ in 1992 (Table 1). In 1992, fruit number per plant was higher in the transgenic $37-81^{\wedge}$ than in the 'Rutgers' control, but was not significantly different from the azygous $37-81^{\wedge}$ (Table 1). However, in 1993 significant differences in fruit number per plant among the three genotypes were not
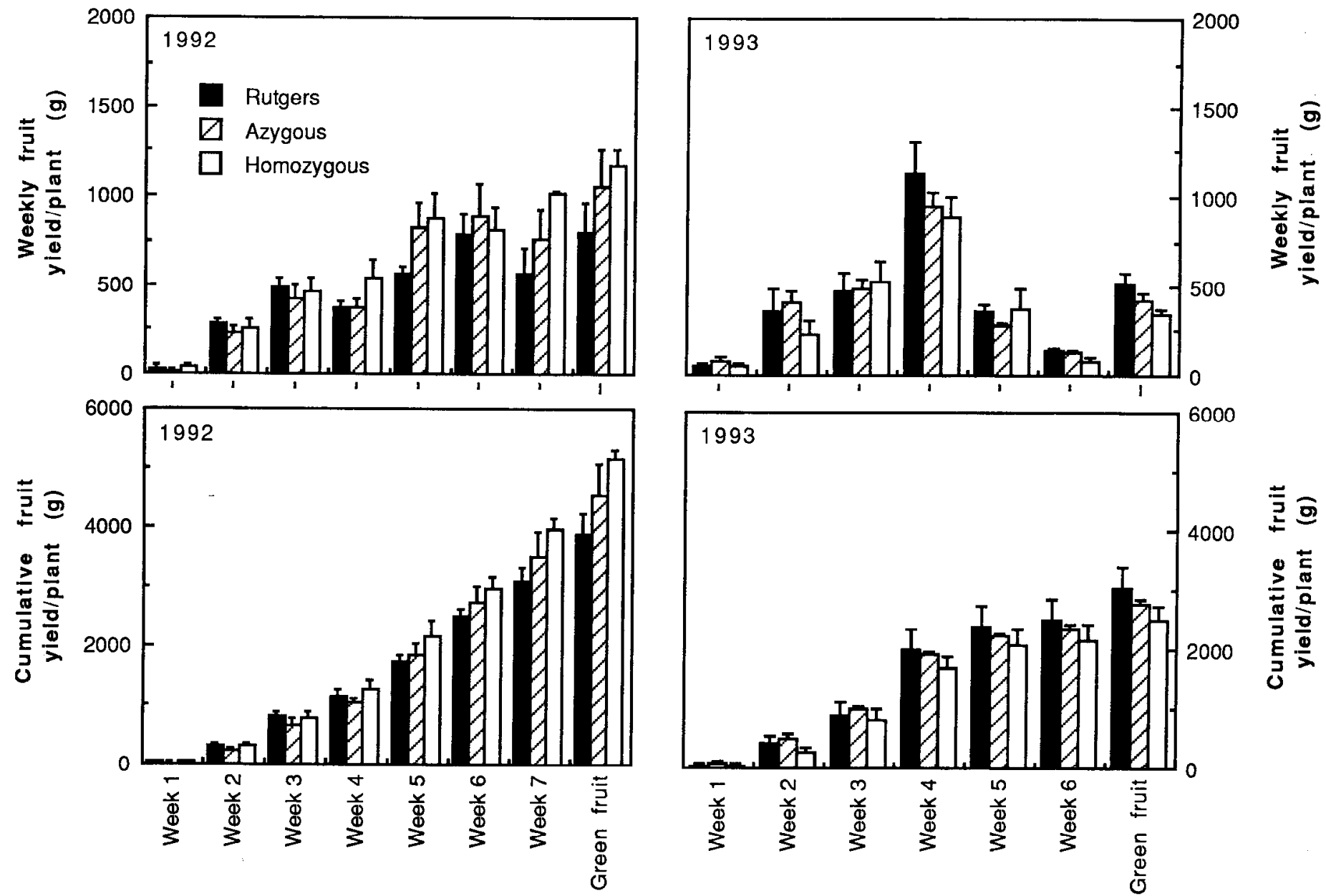

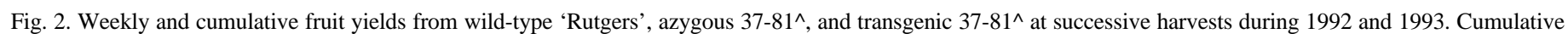

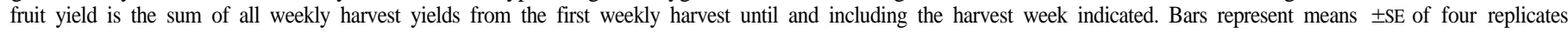
with 10 plants each. 
observed. During the 1993 harvest average fruit weight from the transgenic $37-81^{\wedge}$ and azygous $37-81^{\wedge}$ was similar but lower than the wild-type 'Rutgers' control (Table 1).

Although relative fruit and vegetative yields were similar among the three genotypes for the same year, they differed between the 2 years. To investigate the basis of this finding, we examined fruit fresh weight and fruit number per plant for each weekly harvest during the growing season. During 1992, fruit yield for all genotypes tested increased until the fourth weekly harvest and then remained similar until the last harvest, with many green fruit still remaining on the plants (Fig. 2). This resulted in a continuous increase in cumulative yield during the 1992 harvests. However, in 1993, fruit yield for all three genotypes increased until the fourth weekly harvest and then declined during the fifth and sixth weekly harvests (Fig. 2). This resulted in a slight increase in cumulative yield during later harvests in 1993 (Fig. 2). The patterns of weekly fruit yield and cumulative fruit yield for each year were similar in all three genotypes, except for the seventh weekly harvest of 1992 when higher fruit yield was observed for transgenic $37-81^{\wedge}$ compared to wild-type 'Rutgers' (Fig. 2). Also, cumulative fruit yield for the 1992 harvest, after including green fruit, was higher fortransgenic 37-81" compared to 'Rutgers' (Fig. 2 ). Fruit number for the three genotypes showed a similar pattern during both years, except that in 1992 a higher fruit number was observed in transgenic $37-81^{\wedge}$ than in wild-type 'Rutgers' during the seventh weekly harvest (Fig. 3). For all genotypes in 1992, fruit number increased with each weekly harvest, while in 1993 it
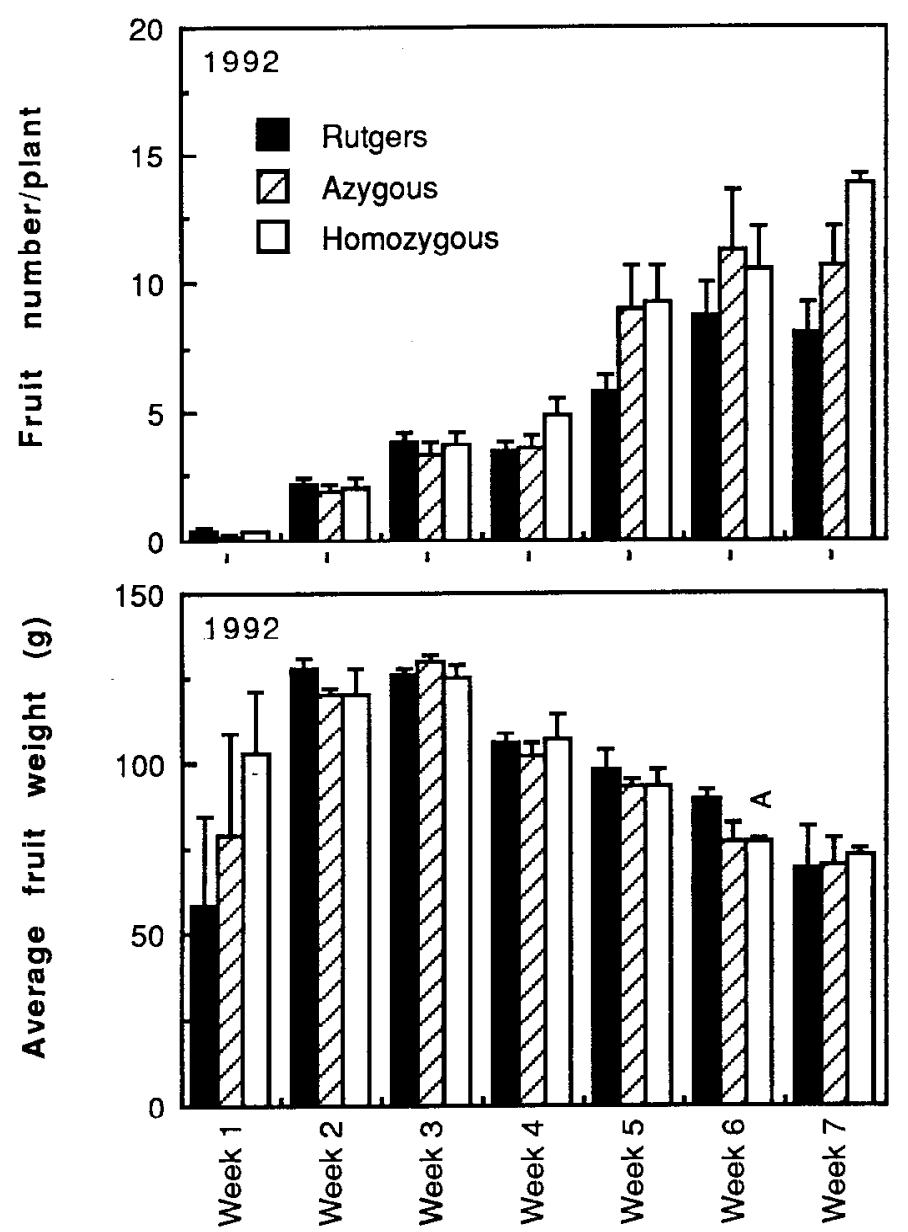

peaked on the fourth weekly harvest and then declined. It is likely that differences in field performance during 1992 and 1993 were due to the climatic conditions. There were many cool, cloudy days during the time of fruit set in 1993 (data not shown), and this may have contributed to decreased yield. However, for the same year all growth parameters were similarly affected for all three genotypes, suggesting that the introduced antisense gene has no deleterious effect on plant and fruit growth even under very different climatic conditions.

Variable patterns for average fruit weight for the three genotypes were observed for the 1992 and 1993 growing seasons, Average fruit weight increased until the third weekly harvest of 1992 before declining and remained constant during the first and second weekly harvests of 1993 before declining (Fig. 3). In 1992, only the sixth weekly harvest showed some decrease in average fruit weight from transgenic $37-81^{\wedge}$ compared to 'Rutgers' and azygous $37-81^{\wedge}$ controls. However, for most weekly harvests in 1993 the average fruit weight from transgenic $37-81^{\wedge}$ and azygous $37-81^{\wedge}$ was lower than wild-type 'Rutgers' (Fig. 3). Although no difference in the average fruit weight was observed between transgenic $37-81^{\wedge}$ and azygous $37-81^{\wedge}$, the average fruit weight of these genotypes was significantly lower than wild-type 'Rutgers' during the 1993 harvest (Table 1). This may be due to tissue culture-induced mutations, including somaclonal variations, that have been reported in many plant species (Maliga, 1984). Collectively, our results indicate that the presence of the antisense PME gene does not affect fruit number or average fruit weight adversely.
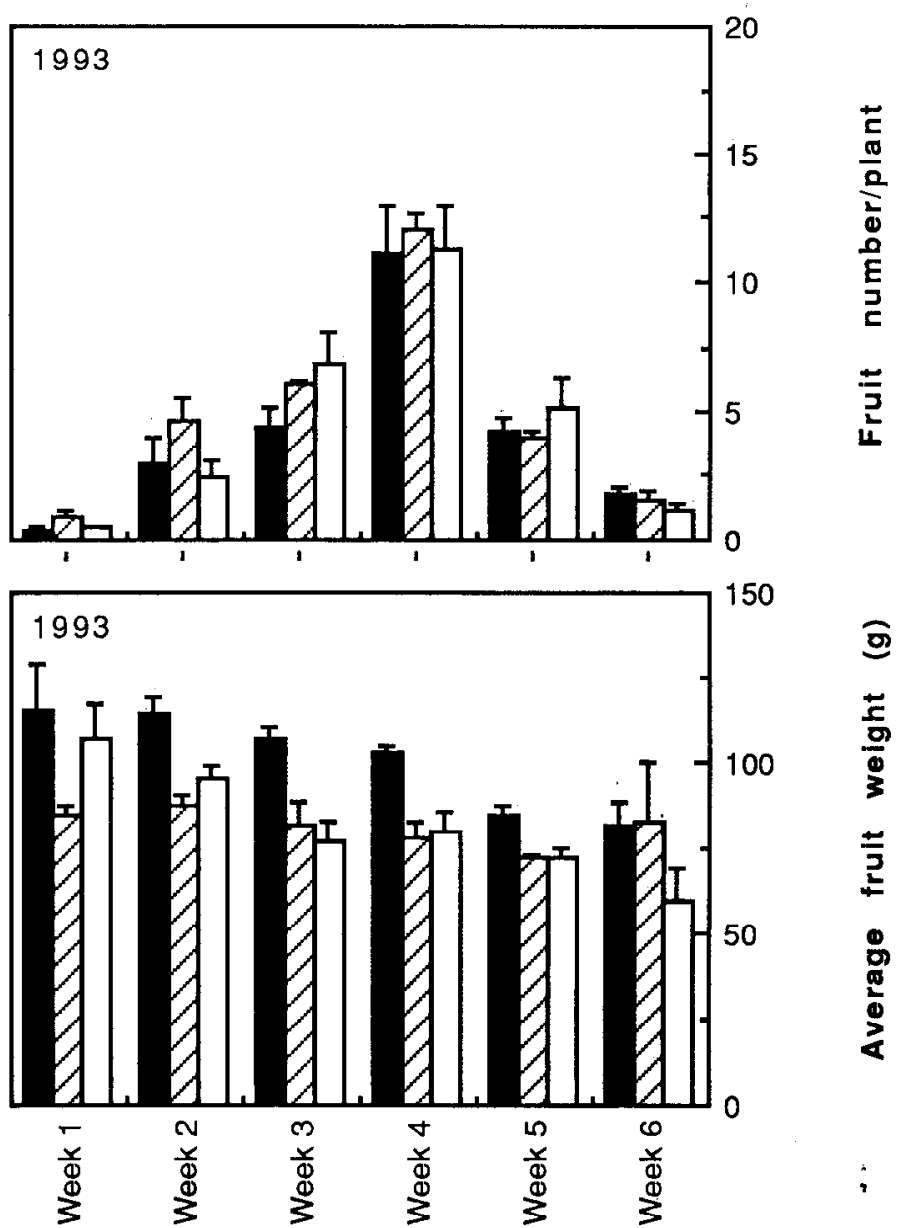

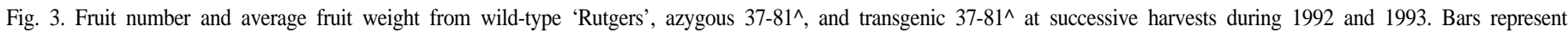
means \pm SE of four replicates with 10 plants each. 
Table 2. Quality grade of wild-type 'Rutgers', azygous 37-81^, and transgenic 37-81" field-grown ripe tomatoes on the day of harvest.

\begin{tabular}{|c|c|c|c|c|c|}
\hline \multirow[b]{2}{*}{ Genotype } & \multirow{2}{*}{$\begin{array}{c}\text { Total } \\
\text { fruit (no.) }\end{array}$} & \multicolumn{4}{|c|}{ Mean fruit distribution by grade (\% of total) $\pm \mathrm{SE}^{2, y}$} \\
\hline & & $\mathrm{A}$ & B & $\mathrm{C}$ & $\mathrm{D}$ \\
\hline Rutgers & 965 & $19.9 \pm 2.4$ & $45.7 \pm 4.3$ & $25.3 \pm 1.1$ & $9.1 \pm 2.4$ \\
\hline Azygous $37-81$ & $1153^{-}$ & $23.2 \pm 2.1$ & $42.2 \pm 3.9$ & $29.1 \pm 5.9$ & $5.5 \pm 0.7$ \\
\hline Transgenic $37-81^{\wedge}$ & 1090 & $18.7 \pm 0.6$ & $42.7 \pm 0.7$ & $29.8 \pm 2.0$ & $8.9 \pm 1.5$ \\
\hline
\end{tabular}

${ }^{\bar{x}}$ Fruit quality grade was determined as described in Materials and Methods. Grade A is the highest quality fruit, while grade D fruit would be rejected as unusable.

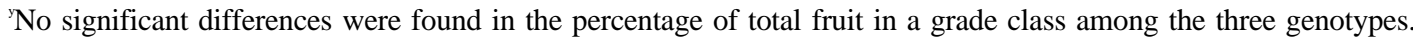

Table 3. Soluble and total solids and $\mathrm{pH}$ of the homogenate of field-grown wild-type 'Rutgers', azygous $37-81^{\wedge}$, and transgenic $37-81^{\wedge}$ fruit. ${ }^{2 y}$

\begin{tabular}{|c|c|c|c|}
\hline Genotype & $\begin{array}{c}\text { Soluble solids } \\
\left({ }^{\circ} \text { Brix }\right)\end{array}$ & $\begin{array}{c}\text { Total solids } \\
(\%)\end{array}$ & $\mathrm{pH}$ \\
\hline Rutgers & $5.95 \pm 0.03(479)$ & $7.61 \pm 0.6(288)$ & $4.43 \pm 0.01(449)$ \\
\hline Azygous $37-81^{\wedge}$ & $6.00 \pm 0.03(373)$ & $7.75 \pm 0.07(228)$ & $4.41 \pm 0.01(360)$ \\
\hline Transgenic $37-81^{\wedge}$ & $6.16 \pm 0.03(488)$ & $7.95 \pm 0.05(286)$ & $4.47 \pm 0.01(450)$ \\
\hline
\end{tabular}

${ }^{\bar{N}}$ Numbers represent means \pm SE for all fruit analyzed.

Numbers in parentheses represent the number of independent fruit samples analyzed.

Effects of the introduced gene on fresh fruit quality. Tomatoes were scored for quality grade on the day of harvest according to standard procedures (Gould, 1992). Although grade is a somewhat subjective measurement, all fruit were subjected to the same standards during visual inspection. As shown in Table 2, no significant differences in fruit quality among the three genotypes were found. Most fruit graded were found to be slightly imperfect (Grade B) but usable for processing. Between $5 \%$ to $10 \%$ of the fruit from each genotype was unusable.

Shelf life of field-grown tomatoes was determined by harvesting ripe fruit followed by storage at room temperature. Tomatoes were discarded when evidence of deterioration or desiccation was observed. 'Rutgers' and azygous $37-81^{\wedge}$ fruit had a similar shelf life, while transgenic $37-81^{\wedge}$ fruit had a slightly shorter shelf life than either 'Rutgers' or azygous $37-81^{\wedge}$ fruit (data not shown). The reduced shelf life of transgenic fruit with reduced PME activity is consistent with our earlier result that PME plays an important role in determining tissue integrity during fruit senescence (Tieman and Handa, 1994). Transgenic fruit have significantly lower levels of bound $\mathrm{Ca}^{2+}$ (Tieman and Handa, 1994), which has been suggested to play a role in fruit firmness by contributing to the cohesiveness of the cell wall (Demarty et al., 1984; Fry, 1986; Grant et al., 1973). A reduction in cell wail integrity may also increase the susceptibility of the fruit to invading pathogens, resulting in decreased shelf life. Contrary to earlier speculation that PME plays a role in fruit softening by enhancing susceptibility of pectins to $\mathrm{PG}$, our data indicate that $\mathrm{PME}$ is involved in maintaining integrity of fruit tissue during ripening and senescence (Tieman and Handa, 1994).

Effects of the introduced gene on tomato processing parameters. Several hundred field-grown fruit from transgenic 37-81^, azygous $37-81^{\wedge}$, and wild-type 'Rutgers' were evaluated for increases in total and soluble solids and $\mathrm{pH}$ of the raw juice (Table 3). Whereas soluble and total solids in wild-type 'Rutgers' and azygous $37-81^{\wedge}$ fruit were not significantly different, transgenic $37-81^{\wedge}$ fruit showed significantly increased levels of soluble and total solids compared to the two controls. The Brix levels in transgenic $37-81^{\wedge}$ fruit were $6.16 \pm 0.03$ compared to $5.95 \pm 0.03$ for 'Rutgers' and $6.00 \pm 0.03$ for azygous $37-81^{\wedge}$. Total solids showed somewhat larger increases $(4.5 \%)$ compared to soluble solids $(3.5 \%)$ in transgenic $37-81^{\wedge}$ fruit. Previously, we reported an increase in soluble solid levels but not in total solids in greenhouse-grown transgenic fruit pericarp (Tieman et al., 1992). It is not clear if this is due to the use of total fruit in the present study instead of only pericarp in the previous study. Also, several factors including environmental conditions, nutrition, stress, age of plant, yield per plant, and cultural practices can influence soluble and total solids levels in tomatoes (Davis and Hobson, 1981). Although the $\mathrm{pH}$ of raw juice from transgenic $37-81^{\wedge}$ fruit was slightly higher than that of control wild-type and azygous fruit, increases in $\mathrm{pH}$ levels detrimental to processing were not observed (Table 3). A slightly higher $\mathrm{pH}$ was observed for raw juice of transgenic fruit may be explained by a reduction in free carboxylic groups in fruit pectins due to the increased degree of methoxylation (Tieman et al., 1992). Since the yield of tomato paste is directly proportional to solids levels, observed increases in soluble and total solids will have a significant impact on the processing performance of tomatoes (Gould, 1992). Overall, we have shown that reduction in fruit PME activity by the expression of its antisense gene has increased the processing quality of fruit without adversely affecting fruit yield or plant growth.

\section{Literature Cited}

Baron-Epel, O., P.K. Gharyl, and M. Schindler. 1988. Pectins as mediators of wall porosity in soybean cells. Planta 175:389-395.

Davies, J.N. and G.E. Hobson. 1981. The constituents of tomato fruit. The influence of environments, nutrition, and genotype. CRC Crit. Rev. Food Sci. Nutr. 15:205-280.

Demarty, M., C. Morvan, and M. Thellier. 1984. Calcium and the cell wall. Plant Cell Environ. 7:477-489.

Finnegan, J. and D. McElroy. 1994. Transgene inactivation: Plants fight back! Bio/Technology 12:883-888.

Fry, S.C. 1986. Cross-linking of matrix polymers in the growing cell walls of angiosperms. Annu. Rev. Plant Physiol. 37:165-186.

Fry, S.C., S. Aldington, P.R. Heterington, and J. Aitken. 1993. Oligosaccharides as signals and substrates in the plant cell wall. Plant Physiol. 103:1-5.

Gaffe, J., D.M. Tieman, and A.K. Handa. 1994. Pectin methylesterase isoforms in tomato (Lycopersicon esculentum) tissues: Effects of expression of a pectin methylesterase antisense gene. Plant Physiol. 105:199-203.

Gould, W.A. 1992. Tomato production, processing and technology. CTI Publications, Baltimore. 
Grant, G.T., E.R. Morris, D.A. Rees, P.J.C. Smith, and D. Thorn. 1973. Biological interactions between polysaccharides and divalent cations: The egg-box model. FEBS Lett. 32:195-198.

Gray, J., S. Picton, Shabbeer, W. Schuch, and D. Grierson. 1992. Molecular biology of fruit ripening and its manipulation with antisense genes. Plant Mol. Biol. 19:69-87.

Grignon, C. and H. Sentenac. 1991. $\mathrm{pH}$ and ionic conditions in the apoplast. Annu. Rev. Plant Physiol. Plant Mol. Biol. 42:103-128.

Hamilton, A.J., G.W. Lycett, and D. Grierson. 1990. Antisense gene that inhibits synthesis of the hormone ethylene in transgenic plants. Nature 346:284-287.

Harpster, M.H., J.A. Townsend, J.D.G. Jones, J. Bedbrook, and P. Dunsmuir. 1988. Relative strengths of the $35 \mathrm{~S}$ cauliflower mosaic virus, $1^{\prime}, 2^{\prime}$ and nopaline synthase promoters in transformed tobacco, sugarbeet and oilseed rape callus tissue. Mol. Gen. Genet. 212:182-190.

Harriman, R.W., D.M. Tieman, and A.K. Handa. 1991. Molecularcloning of tomato pectin methylesterase gene and its expression in Rutgers, ripening inhibitor, nonripening, and Never ripe tomato fruits. Plant Physiol. 97:80-87.

Hewitt, J.D. and T.C. Garvey. 1987. Wild sources of high soluble solids in tomato, p. 45-54. In: D.J. Nevins and R. A. Jones (eds.). Tomato biotechnology. Alan R. Liss, New York.

Huber, D.J. 1983. The role of cell wall hydrolases in fruit softening. Hort. Rev. 5:169-219.

Klee, H.J., M.B. Hayford, K.A. Kretzmer, G.F. Barry, and G.M. Kishore. 199 1. Control of ethylene synthesis by expression of a bacterial enzyme in transgenic tomato fruits. Plant Cell 3: 1187-1 193.

Kramer, M., R. Sanders, H. Bolkan, C. Waters, R.E. Sheehy, and W.R. Hiatt. 1992. Postharvest evaluation of transgenic tomatoes with reduced levels of polygalacturonase: processing, firmness and disease resistance. Postharvest Biol. Technol. 1:241-255.

Leach, G.H. Schols, L. Pyle, and K. Niranjan. 1993. Influence of processing regime on certain characteristics of diffusionally extracted apple juice. Intl. J. Food Sci. Technol. 28:261-272.

Maliga, P. 1984. Isolation and characterization of mutants in plant cell culture. Annu. Rev. Plant Physiol. 35:519-542.

Miers, J.C., J.R. Wagner, and D.W. Sanshuck. 1967. Consistency of tomato products. II. Effect of $\mathrm{pH}$ during extraction on tomato juice consistency. Food Technol. 21:923-926.

Moustacas, A.M., J. Nari, M. Borel, G. Noat, M. Crasnier, M. Borel, and J. Ricard. 1991. Pectin methylesterase, metal ions and plant cell-wall extension: The role of metal ions in plant cell-wall extension. Biochem.
J. 155:191-197.

Nari, J., G. Noat, and J. Ricard. 1991. Pectin methylesterase, metal ions and plant cell-wall extension: Hydrolysis of pectin by plant cell-wall pectin methylesterase. Biochem. J. 270:343-350.

Northcote, D.H. 1986. Control of pectin synthesis and deposition during plant cell wall growth, p. 134-140. In: M.L. Fishman and J.J. Jen (eds.). Chemistry and function of pectins. Amer. Chem. Soc., Washington, D.C.

Odell, J.T., F. Nagy, and N.-H Chua. 1985. Identification of DNA sequences required for activity of the cauliflower mosaic virus $35 \mathrm{~S}$ promoter. Nature 313:810-812.

Oeller, P.W., L.M. Wang, L.P. Taylor, D.A. Pike, and A. Theologis. 1991. Reversible inhibition of tomato fruit senescence by antisense 1aminocyclopropane-1-carboxylate synthase. Science 254:437-439.

Pressey, R. and J.K. Avants. 1982. Solubilization of cell walls by tomato polygalacturonases: Effects of pectinesterases. J. Food Biochem. 6:56-74. Rexova-Benkova, L. and O. Markovic. 1976. Pectic enzymes, p. 323385. In: R.S. Tipton and D. Horton (eds.). Advances in carbohydrate chemistry and biochemistry. vol. 33. Acad. Press, New York.

Rick, C.M. 1974. High soluble solids content in large-fruited tomato lines derived from a green-fruited species. Hilgardia 42:493-510.

Sajjaanantakul, T. and L.A. Pitifer. 1991. Pectinesterase, p. 135-165. In: R.H. Walter (ed.). The chemistry and technology of pectins. Acad. Press, San Diego.

Schuch, W., J. Kanczler, D. Robertson, G. Hobson, G. Tucker, D. Grierson, S. Bright, and C. Bird. 1991. Fruit quality characteristics of transgenic tomato fruit with altered polygalacturonase activity. HortScience 26:1517-1520.

Sexton, R. and J.A. Roberts. 1982. Cell biology of abscission. Annu. Rev. Plant Physiol. 33:133-162.

Stevens, M.A. 1986. Inheritance of tomato quality components. Plant Breeding Rev. 4:273-311.

Tabler, M. 1993. Antisense RNA in plants: a tool for analysis and suppression of gene function, p. 237-258. In: K.S. Roubelakis-Angelakis and K. Tran Thanh Van (eds.). Morphogenesis in plants. Plenum Press, New York.

Tieman, D.M. and A.K. Handa. 1994. Pectin methylesterase regulates cation levels and tissue integrity in ripening tomato fruits. Plant Physiol. 106:429436.

Tieman, D.M., R.W. Harriman, G. Ramamohan, and A.K. Handa. 1992. An antisense pectin methylesterase gene alters pectin chemistry and soluble solids in tomato fruit. Plant Cell 4:667-679. 